\title{
Pengaruh Massage Kaki terhadap Penurunan Insomnia pada Lansia di Banjar Temesi Desa Temesi Kabupaten Gianyar
}

\author{
I Gede Putu Widi Widiana', ${ }^{1}$ Made Sudiari ${ }^{2}$, Ni Komang Sukraandini ${ }^{3}$ \\ ${ }^{1-3}$ Sekolah Tinggi Ilmu Kesehatan Wira Medika Bali \\ Email: gdwidiana97@gmail.com
}

Published: $14 / 03 / 2020$

\begin{abstract}
Insomnia is an inability to sleep even if the adequate opportunity and circumstances to sleep are present. This disorder very common happening among the elderly. Insomnia on the elderly associated with excessive daytime sleepiness, difficulty in concentrating, mood disturbances, depression, frequent number of fall accidents, excessive hypnotic medication use, and low quality of life. Foot massage is a form of therapy that could reduce the level of insomnia in the elderly. This study aimed to know the effect of foot massage on insomnia among the elderly in Banjar Temesi, Temesi Village, Gianyar Regency. This was a preexperimental one group pre-posttest study using a purposive sampling technique that involved 15 elderlies. There were 9 participants (60\%) who were experiencing moderate insomnia before the foot massage intervention, while after the foot massage intervention, 13 participants $(86.7 \%)$ were experiencing mild insomnia. Wilcoxon statistical test showed that the $p+$ value was $0.001(p<\alpha, \alpha=0.05)$. This result indicated which also means that the foot massage was able to reduce the level of insomnia among the elderly in Banjar Temesi, Temesi Village, Gianyar Regency. We suggest using foot massage as an alternative intervention to reduce insomnia in the elderly.
\end{abstract}

Keywords: elderly, foot massage, insomnia

Abstrak
Salah satu masalah yang sering terjadipada lansia adalah insomnia yaitu ketidak mampuanuntuk tidur walaupun ada keinginanuntuk melakukannya. Dampak Insomnia pada lansia yaitu mengantuk berlebihan di siang hari, gangguan atensi dan memori, mood, depresi, sering terjatuh, penggunaan hipnotik yang tidak semestinya dan penurunan kualitas hidup. Pada tahap ini tentunya lansia membutuhkan terapi , salah satunya dengan di berikan massage kaki. Penelitian ini bertujuan untuk mengetahui pengaruh Massage Kaki terhadap penurunan insomnia pada Lansia di Banjar Temesi Desa Temesi Kabupaten Gianyar. Penelitian ini menggunakan rancangan desain pre eksperimental one group pre test-post test. Sampel terdiri dari 15 orang diambil secara Purposive Sampling. Hasil didapatkan sebelum diberikan massage kaki pada lansia mengalami insomnia sedang sebanyak 9 orang $(60 \%)$, sesudah diberikan massage kaki menjadi insomnia rendah 13 responden $(86,7 \%)$. Berdasarkan uji statistik wilcoxon didapatkan hasil bahwa nilai $P+$ value $+0,001$ yang berarti $P<\alpha(0,05)$ berarti ada pengaruh massage kaki terhadap penurunan insomnia pada lansia di Banjar Temesi Desa Temesi. Berdasarkan hasil penelitian tersebut, disarankan agar massage kaki dapat digunakan sebagai salah satu alternatif dalam menurunkan insomnia pada lansia.

Kata kunci : insomnia, lansia massage kaki 


\section{PENDAHULUAN}

Peningkatan jumlah penduduk pada lansia disebabkan oleh adanya tingkat sosial ekonomi masyarakat yang meningkat, kemajuan dalam bidang pelayanan kesehatan, dan tingkat pengetahuan masyarakat yang semakin meningkat. Salah satu indikator keberhasilan pembangunan adalah semakin meningkatnya usia harapan hidup penduduk (Sunaryo, 2016). Semakin meningkat umur harapan hidup mengakibatkan jumlah penduduk lanjut usia semakin bertambah banyak, bahkan cenderung lebih cepat dan pesat (Martono \& Pranarka, 2011). Menurut World Health Organization (2015) pada tahun 2013-2050, penduduk lansia di dunia akan menduduki peringkat teratas dibandingkan dari golongan usia dibawahnya.

Berdasarkan data populasi lansia pada tahun 2017 terdapat 23,66 juta jiwa penduduk lansia di Indonesia. Diprediksi jumlah penduduk lansia akan terus meningkat dimana pada tahun 2020 meningkat menjadi 28,08 juta jiwa, pada tahun 2025 meningkat menjadi 33,69 juta jiwa, pada tahun 2030 meningkat menjadi 40,95 jua jiwa, dan jumlah tersebut akan terus meningkat menjadi 48,19 juta jiwa pada tahun 2035. Suatu negara dikatakan berstruktur tua jika mempunyai populasi lansia diatas $7 \%$ (Kementerian Kesehatan RI, 2017).

Jumlah penduduk lansia yang berumur 60 tahun keatas di Bali tahun 2017 yaitu sebanyak 463,039 ribu jiwa. Jumlah penduduk lanjut usia tertinggi pertama berada di Kabupaten Gianyar dengan jumlah 86,061 jiwa, dilanjutkan oleh Kabupaten Badung dengan jumlah 78,170 jiwa, Kabupaten Tabanan dengan jumlah 73,778 jiwa dan jumlah penduduk lanjut usia paling rendah berada di Kabupaten Bangli dengan jumlah 21,777 jiwa ( Dinas Kesehatan Provinsi Bali, 2017 ).

Lanjut usia merupakan periode akhir dalam kehidupan manusia dimana seseorang mulai mengalami perubahan dalam hidupnya yang ditandai adanya perubahan fisik, kelemahan, meningkatnya kerentanan terhadap penyakit, serta perubahan fisiologi yang terjadi (Maheshwari, 2016). Menurut Depkes RI (2015) penduduk lansia merupakan penduduk yang berumur 60 tahun atau lebih. Lansia dapat dikatakan usia emas karena tidak semua orang dapat mencapai usia tersebut, maka orang yang berusia lanjut memerlukan tindakan keperawatan, baik yang bersifat promotif maupun preventif, agar lansia dapat menikmati masa usia emas serta menjadi usia lanjut yang berguna dan bahagia (Maryam, 2015).

Salah satu masalah yang sering terjadipada lansia adalah insomniaatau susah tidur yaitu ketidakmampuanuntuk tidur walaupun ada keinginanuntuk melakukannya(Kurniawan,2015).Dampak Insomnia pada lansia yaitu 1) mengantuk berlebihan di siang hari, 2) gangguan atensi dan memori, 3) mood, 4) depresi, 5) sering terjatuh, 6) penggunaan hipnotik yang tidak semestinya dan 7) penurunan kualitas hidup (Prananto, 2016).Insomnia dapat mengancam jiwa baik secara langsung (misalnya insomnia yang bersifat keturunan dan fatal serta apnea tidur obstruktif) atau secara tidak langsung misalnya kecelakaan akibat gangguan tidur (Darmojo, 2015). Di Amerika Serikat, lansia yang mengalami kecelakaan akibat gangguan tidur per tahun sekitar 80 juta orang, biaya kecelakaan yang berhubungan dengan gangguan tidur per tahun sekitar \$100 juta (World Health Organization, 2015).

Menurut National SleepFoundation (2015) sekitar 67\% dari 1.508 lansia di Amerika usia 65 tahun ke atasmelaporkan mengalami insomnia dan sebanyak 7,3\% lansia mengeluhkangangguan memulai dan mempertahankan tidur. Kebanyakan lansiaberesiko mengalami insomnia yang disebabkan karena pensiunan, kematian pasangan atau teman dekat, peningkatan obat-obatan danpenyakit yang dialami, di Indonesia insomnia menyerang sekitar 50\% 
dari 23,66 juta jiwayang berusia 65 tahun, setiap tahun diperkirakan sekitar $20 \%$ sampai dengan 50\% lansia dilaporkan mengalamiinsomnia dan sekitar $17 \%$ mengalami insomnia yang serius. Prevalensiinsomnia pada lansia cukup tinggi yaitu sekitar 67\% (Puspitosari, 2015). Di Provinsi Bali tahun 2015 diperkirakan tiap tahun $20 \%$ sampai dengan $40 \%$ orang dewasa dan lansia mengalami insomnia sebanyak 112.876 jiwa $(16,59 \%)$.

Insomnia pada lansia disebabkan oleh beberapa faktor, yaitu faktor status kesehatan, penggunaan obat-obatan, kondisi lingkungan, stres psikologis, diet/nutrisi, gaya hidup menyumbangkan insomnia pada usia lanjut (Prananto, 2016).Insomnia pada lansia juga dihubungkan dengan penurunan memori, konsentrasi terganggu dan perubahan kinerja fungsional. Perubahan yang sangat menonjol yaitu terjadi penurunan gelombang alfa dan meningkatnya frekuensi terbangun di malam hari atau meningkatnya fragmentasi tidur karena seringnya terbangun (Darmojo, 2015). Penelitian Hermayudi (2012), menunjukkan gambaran karakteristik responden didapatkan bahwa lansia mengalami insomnia sebanyak $54,1 \%$. Penelitian Laraswati (2014), didapatkan hasil penelitian paling banyak lansia mengalami insomnia kategori tinggi yaitu sebanyak $46,7 \%$.

Penanganan yang dapat digunakan untuk mengatasi insomniaantara lain terapi farmakologi dan terapi nonfarmakologi. Terapifarmakologi dapat dilakukan dengan pemberian obat tidur, tetapipenggunaan jangka panjang dapat mengganggu tidur danmenyebabkan masalah yang lebih serius seperti ketergantungan akan obat, penurunan metabolisme pada lansia, penurunan fungsi ginjal dan menyebabkan kerusakan fungsi kognitif (Aziz, 2014). Penanganan Terapi non farmakologi yang dapat digunakan untuk mengatasi insomnia pada lansiaantara lain terapi rekreasi, terapi musik, massage kaki, pijat, yoga, relaksasi progresif, meditasi dan aromaterapi (Rahmawati, 2015). Massage kaki merupakan terapi non farmakologis, hanyalah menggunakan tangan manusia dan dapat dilakukan sendiri tanpa menggunakan bantuan fisik dari orang lain, dalam melakukan massage pada otot - otot kaki maka dapat memperlancar sirkulasi darah mengalir ke jantung (Pamungkas,2015).

Massage kaki adalah stimulasi pada kulit dan jaringan dibawahnya dengan menggunakan berbagai tingkatan tekanan tangan untuk mengurangi nyeri, membuat rileks atau meningkatkan sirkulasi. Massage merupakan salah satu terapi alternative dan komplementer yang menggabungkan berbagai teknik dalam keperawatan seperti sentuhan, teknik relaksasi dan teknik distraksi (Closky \& Bulechek, 2015).

Massage memberikan rangsangan berupa tekanan pada saraf pada telapak kaki. Rangsangan tersebut diterima oleh reseptor saraf (saraf penerima rangsangan). Rangsangan yang diterima ini akan diubah oleh tubuh menjadi aliran listrik, kemudian aliran listrik tersebut langsung dikirim ke otak. Sinyal yang dikirim langsung ke otak dapat melepaskan ketegangan dan memulihkan keseimbangan ke seluruh tubuh (Dewi \& Hartati, 2015). Menurut Gunawan (2015), tekanan titik saraf pada telapak kaki memberikan rangsangan bioelektrik yang dapat melancarkan sirkulasi aliran darah dan cairan tubuh untuk menyalurkan nutrisi serta oksigen ke sel-sel tubuh menjadi lancar yang akan memberikan efek relaksasi, dalam keadaan rileks inilah yang dapat memberikan stimulus ke Reticular Activating System (RAS) yang berlokasi di batang otak teratas yang dapat mempertahankan kewaspadaan dan terjaga. Keadaan rileks ini stimulus pada RAS akan semakin menurun. Dengan demikian akan diambil alih oleh batang otak yang lain yang disebut Bulbar Synchronizing Region (BSR). BSR akan melepaskan serum serotonin yang dapat memberikan efek mengantuk sehingga 
dapat meningkatkan kualitas tidur, Menurut UU No 382014 perawat bisa melakukan terapi komplementer.

Berdasarkan data dinas kesehatan kabupaten gianyar (2018) jumlah penduduk lansia di kabupaten Gianyar sebanyak 86.061 lansia dimana untuk kabupaten gianyar jumlah lansia terbanyak ada di wilayah UPT Kesmas Gianyar 1 dengan jumlah lansia 5.435. Berdasarkan studi pendahuluan yang dilakukan pada tanggal 6 Agustus 2019 di Puskesmas 1 Gianyar di dapat data, jumlah lansia di wilayah kerja Puskesmas 1 Gianyar yang mewilayah 10 desa. Menurut data desa Temesi 422 lansia. Gangguan yang paling besar dikeluhkan oleh lansia pada tahun 2018 adalah insomnia sebanyak 52 orang.Menurut data yang berada wilayah kerja di Puskesmas 1 Gianyar, bahwa kunjungan lansia dengan insomnia yang paling banyak berasal dari BanjarTemesi Desa Temesi sebanyak 23 orang.

Berdasarkan hasil study pendahuluan yang dilakukan peneliti di posyandu lansia di Desa Temesidengan melakukan wawancara terhadap 5 orang lansia yang sudah mengalami Insomnia. Lansia yang terindikasi mengalami insomnia sebagian besar mengatakan bahwa susah memulai tidur dan sering terbangun pada malam hari. Akibatnya 2 dari 5 merasa lemas, sedangkan 3 lansia sering terjatuh ketika beraktivitas. Upaya yang dilakukan oleh lansia untuk mengatasi gangguan tidur yang selama ini dilakukan adalah minum obat penenang yang diberikan puskesmas. Upaya lain yang dilakukan lansia adalah dengan, menonton televisi, mejejahitan, mendengar musik tradisional Bali, di Banjar Temesi Desa Temesi belum pernah di lakukan penelitian tentang pemberian Massage Kaki terhadap insomnia pada lansia.

\section{METODE PENELITIAN}

Penelitian ini menggunakan rancangan desain pre eksperimental one group pre test-post test.fokus penelitian ini adalah insomnia pada lansia. Populasi dalam penelitian ini adalah lansia yang mengalami insomniadi Banjar Temesi Desa Temesi Kabupaten Gianyarsebanyak 23 orang. Sampel dalam penelitian iniberjumlah 15 orang diambil secara Purposive Sampling dengan kriteria lansia yang bersedia menjadi responden, lansia yang mengalami Insomnia sekunder, mampu berkomunikasi secara verbal, dan lansia tidak mengonsumsi obat tidur. Penelitian menggunakan Insomnia Rating Scale untuk mengukur insomnia. Teknik analisa data yang digunakan peneliti adalah uji statistik Wilcoxon.

\section{HASIL DAN PEMBAHASAN}

Tabel 1. Distribusi Frekuensi Responden Berdasarkan Umur lansia

\begin{tabular}{llll}
\hline $\begin{array}{l}\text { Umur } \\
\text { Responden }\end{array}$ & $\begin{array}{l}\text { Frekuensi } \\
(\mathrm{n})\end{array}$ & $\begin{array}{l}\text { Persentase } \\
(\%)\end{array}$ \\
\hline $60-74$ & 13 & 86,7 & \\
$75-90$ & 2 & 13,3 & \\
\hline Total & 15 & 100,0 & \\
\hline \multicolumn{5}{r}{ Berdasarkan } & tabel & 1 data yang
\end{tabular}
didapatkan dalam penelitian ini bahwa responden dalam penelitian ini yaitu dari 15 responden (100\%) dengan usia 60-74 tahun sebanyak 13 responden $(86,7 \%)$.

Tabel 2. Distribusi Frekuensi Responden Berdasarkan Jenis kelamin lansia yang mengalami insomnia di Banjar Temesi Desa Temesi tahun 2019

\begin{tabular}{|c|c|c|}
\hline $\begin{array}{l}\text { Jenis } \\
\text { Kelamin }\end{array}$ & $\begin{array}{l}\text { Frekuensi } \\
\text { (n) }\end{array}$ & $\begin{array}{l}\text { Persentase } \\
(\%)\end{array}$ \\
\hline Perempuan & 4 & 26,7 \\
\hline Laki-Laki & 11 & 73,3 \\
\hline Total & 15 & 100,0 \\
\hline \multicolumn{3}{|c|}{$\begin{array}{l}\text { Berdasarkan tabel } 2 \text { data yang } \\
\text { didapatkan dalam penelitian ini diketahui } \\
\text { dari } 15 \text { responden }(100 \%) \text { sebagian besar } \\
\text { berjenis kelamin laki-laki yaitu sebanyak } 11 \\
\text { responden }(73,3 \%) \text {. }\end{array}$} \\
\hline
\end{tabular}


Tabel. 3 Distribusi Frekuensi Responden Berdasarkan tingkat pendidikan lansia yang mengalami insomnia di Banjar Temesi Desa Temesi tahun 2019

\begin{tabular}{lll}
$\begin{array}{l}\text { Tingkat } \\
\text { Pendidikan }\end{array}$ & $\begin{array}{l}\text { Frekuensi } \\
(\mathrm{n})\end{array}$ & $\begin{array}{l}\text { Persentase } \\
(\%)\end{array}$ \\
\hline Tidak Sekolah & 9 & 60,0 \\
SD & 4 & 26,7 \\
SMP & 2 & 13,3 \\
\hline Total & 15 & 100,0 \\
\hline \multicolumn{2}{c}{ Berdasarkan tabel 3 } & data yang
\end{tabular}

didapatkan dalam penelitian ini diketahui dari 15 responden $(100 \%)$ tingkat pendidikan yang paling banyak tidak sekolah yaitu sebanyak 9 responden $(60,0 \%)$.

Tabel 4. Distribusi Frekuensi Responden Berdasarkan pekerjaan lansia yang mengalami insomnia di Banjar Temesi Desa Temesi tahun 2019

\begin{tabular}{|c|c|c|}
\hline $\begin{array}{l}\text { Status } \\
\text { Perkawinan }\end{array}$ & $\begin{array}{l}\text { Frekuensi } \\
\text { (n) }\end{array}$ & $\begin{array}{l}\text { Persentase } \\
(\%)\end{array}$ \\
\hline Petani & 10 & 66,7 \\
\hline Tidak Bekerja & 5 & 33,3 \\
\hline Total & 15 & 100,0 \\
\hline
\end{tabular}
didapatkan dalam penelitian ini diketahui dari 15 responden sebagian bekerja sebagai petani yaitu sebanyak 10 responden $(66,7 \%)$.
Tabel 5. Distribusi Frekuensi Hasil Identifikasi insomnia pada lansia di Banjar Temesi Desa Temesi sebelum diberiakan Massage kaki

\begin{tabular}{|c|c|c|}
\hline $\begin{array}{l}\text { Insomnia sebelum } \\
\text { diberikan Massage } \\
\text { kaki }\end{array}$ & $\begin{array}{l}\text { Frekuensi } \\
\text { (n) }\end{array}$ & $\begin{array}{l}\text { Persentase } \\
(\%)\end{array}$ \\
\hline Insomnia Rendah & 6 & 40,0 \\
\hline Insol & 9 & 60,0 \\
\hline Total & 15 & 100,0 \\
\hline $\begin{array}{l}\text { Berdasarka } \\
\text { lapatkan dalam } \\
\text { esponden }(100 \%) \\
\text { nengalami insomn } \\
(60 \%) \text {. }\end{array}$ & tabel 5 & $\begin{array}{l}\text { lata yang di } \\
\text { ni dari } 15\end{array}$ \\
\hline \multicolumn{3}{|c|}{$\begin{array}{l}\text { Tabel 6. Distribusi Frekuensi Hasil } \\
\text { Identifikasi insomnia pada lansia di } \\
\text { Banjar Temesi Desa Temesi setelah } \\
\text { diberiakan Massage kaki }\end{array}$} \\
\hline $\begin{array}{l}\text { Insomnia setelah } \\
\text { diberikan } \\
\text { Massage kaki } \\
\end{array}$ & $\begin{array}{l}\text { Frekuensi } \\
\text { (n) }\end{array}$ & $\begin{array}{l}\text { Persentase } \\
(\%)\end{array}$ \\
\hline Tidak insomnia & 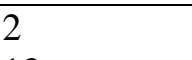 & 13,3 \\
\hline Insomnia rendah & 13 & 86,7 \\
\hline Total & 15 & 100,0 \\
\hline
\end{tabular}

Berdasarkan tabel 6 data yang didapat dalam penelitian ini dari 15 responden $(100 \%)$ sebagian besar mengalami insomnia rendah yaitu sebanyak 13 $(86,7 \%)$.

Tabel7. Distribusi Frekuensi analisa Pengaruh Massage kaki Terhadap Penurunan Insomniapada Lansia di Banjar Temesi Desa Temesi Kabupaten Gianyar

\begin{tabular}{|c|c|c|c|c|c|}
\hline \multirow[b]{2}{*}{$\begin{array}{l}\text { Kategori } \\
\text { Insomnia }\end{array}$} & \multicolumn{2}{|c|}{ Hasil Pre Test } & \multicolumn{2}{|c|}{ Hasil Post Test } & \multirow[b]{2}{*}{$P$ Value } \\
\hline & Frekuensi & Persentase (\%) & Frekuensi & Persentase (\%) & \\
\hline Tidak Insomnia & 0 & 0,0 & 2 & 13,3 & 0.001 \\
\hline Insomnia Rendah & 6 & 40,0 & 13 & 86,7 & \\
\hline Insomnia Sedang & 9 & 60,0 & 0 & 0,0 & \\
\hline Total & 15 & 100,0 & 15 & 100,0 & \\
\hline
\end{tabular}

mengalami insomnia sedang sebanyak 9

responden $(60 \%)$, sedangkan setelah 
Insomnia merupakan gangguan tidur paling sering pada usia lanjut, yang ditandai dengan ketidakmampuan untuk mengawali tidur, mempertahankan tidur, bangun terlalu dini atau tidur yang tidak menyegarkan.Insomnia pada lansia disebabkan oleh beberapa faktor, yaitu dari faktorstatus kesehatan, penggunaan obatobatan, kondisi lingkungan, stres psikologis, diet/nutrisi, gaya hidup menyumbangkan insomnia pada usia lanjut. Insomnia padausia lanjut dihubungkan dengan penurunan memori, konsentrasi terganggu danperubahan kinerja fungsional. Perubahan yang sangat menonjol yaitu terjadipengurangan pada gelombang lambat, terutama stadium 4 , gelombang alfa menurun dan meningkatnya frekuensi terbangun di malam hari atau meningkatnya fragmentasitidur karena seringnya terbangun (Darmojo, 2015).

Menurut Gunawan (2015) insomnia sedang adalah insomnia yang berhubungan dengan kecemasan, misalnya akan menghadapi ujian atau wawancara pekerjaan. Insomnia jenis ini juga berhubungan dengan stress situasional seperti duka cita, kehilangan orang yang dicintai, atauhampir semua perubahan dalam kehidupan. Insomnia ini terjadi antara 2-4 minggu.

Hasil penelitian ini didukung oleh penelitian yang dilakukan olehSudiyanto, Henry. \& Wahid, Abdul (2017), dengan judul "Pengaruh massage kaki terhadap insomnia pada pasien hospitalisasi di RS Islam Sakinah Mojokerto. Jumlah sampel sebanyak 30 orang. Hasil penelitian menunjukan data skor insomnia pada kelompok kontrol sebelum dan sesudah diberikan Massage kaki menunjukan penurunan insomnia dengan hasil yang tidak signifikan, sebaliknya pada kelompok perlakuan menunjukan penurunan yang signifikan. Persamaan penelitian Sudiyanto, Henry. \& Wahid, Abdul dengan penelitian yang dilakukan peneliti adalah variabel terikat yaitu penurunan insomnia.
Perbedaan dari penelitian Sudiyanto, Henry. \& Wahid, Abdul dengan yang dilakukan peneliti adalah peneliti Sudiyanto, Henry. \& Wahid, Abdul menggunakan kelompok kontrol dan perlakuan sedangkan peneliti hanya menggunakan kelompok perlakuan saja, jumlah sampel yang digunakan juga berbeda penelitian Sudiyanto, Henry. \& Wahid, Abdul menggunakan jumlah sampel sebanyak 30 responden sedangkan jumlah sampel yang digunakan peneliti sebanyak 15 responden.

Peneliti berpendapat kemampuan responden dalam mengatasi insomnia belum efektif sehingga insomnia yang dialami responden sebagian besar masih dalam kategori sedang. Dalam penelitian ini sebagian besar yang mengalami insomnia dengan jenis kelamin laki-laki yaitu sebanyak 11 responden dari 15 responden. Sebagian besar lansia yang menjadi responden bekerja sebagai petani yaitu sebanyak 10 orang dan yang tidak bekerja sebanyak 5 orang. lansia yang bekerja sebagai petani memang kurang mendapatkan waktu istirahat karena dari pagi lansia yang bekerja sebagai petani harus pergi ke sawah dan siang hari mereka kembali ke rumah untuk makan siang. Sore hari mereka kembali ke sawah untuk melanjutkan pekerjaan mereka. Dari pekerjaan itu mereka akan cepat merasakan lelah dan capeksehingga kebutuhan istirahat juga meningkat, namun karena rasa capek dan letihtersebut juga dapat menyebabkan lansia sulit untuk tidur karena tubuh yang merasa sakitakibat dari pekerjaannya. Jika insomnia dibiarkan terus menerus juga akan berdampak pada kesehatan lansia dalam melakukan aktivitas sehari hari. Dalam hal ini membutuhkan upaya yang mudah dan efektif dalam penurunan insomnia pada lansia. Salah satu cara nonfarmakologi yang bisa digunakan untuk menurukan insomnia dengan cara menggunakan massage kaki.

Massage memberikan rangsangan berupa tekanan pada saraf pada telapak 
kaki. Rangsangan tersebut diterima oleh reseptor saraf (saraf penerima 5 rangsangan). Rangsangan yang diterima ini akan diubah oleh tubuh menjadi aliran listrik, kemudian aliran listrik tersebut langsung dikirim ke otak. Sinyal yang dikirim langsung ke otak dapat melepaskan ketegangan dan memulihkan keseimbangan ke seluruh tubuh (Dewi \& Hartati, 2015)

Hasil penelitian ini didukung oleh penelitian Wening (2014) dengan judul pengaruh massage kaki terhadap Intensitas nyeri pasca sectio caesaria di ruang bougenfil RSUD Dr. Adhyatma MPH. Institusi: Poliklinik Kebidanan Kemenkes RI, Semarang dengan jumlah sampel 32 orang. Hasil penelitian menunjukan bahwa sebelum dilakukan massage kaki rata-rata intesitas nyeri pada skala 5,44 (Kisaran 29). Persamaan yang terdapat dalam penelitian Wening dengan peneliti terdapat pada variabel bebas yaitu pengaruh massage kaki. Perbedaan yang didapat dalam penelitian Wening dengan yang peneliti lakukan adalah jumlah responden yang digunakan penelitian Wening menggunakan 32 responden sedangkan yang peneliti ambil sebanyak 15 responden.

Peneliti berpendapat bahwa setelah diberikan massage kaki kepada responden terjadi penurunan insomnia dari insomnia sedang terjadi penurunan ke insomnia rendah sebanyak 13 responden $(86,7 \%)$ sedangkan dari insomnia rendah menjadi tidak insomnia sebanyak 2 responden $(13,3 \%)$. Lansia yang tidak mengangalami penurunan insomnia itu mengalami insomnia rendah. Sebagian besar responden bekerja sebagai petani. Tentu dalam hal ini pemberian massage kaki sangat cocok diberikan kepada responden mengingat responden sudah lanjut usia dan pasti sering mengeluh pegal dan sakit. Responden sangat suka saat diberikan massage kaki karena responden merasa nyaman setelah di berikan massage kaki. Tidak ada penolakan dalam pemberian massage kaki karena responden sangat ingin mengetahui bagimana penanganan yang bisa dilakukan untuk menurunakan insomnia supaya bisa diterapkan jika responden mengalami insomnia. Jika massage kaki secara tepat akan berdampak positif terutama dalam menurunkan insomnia.

Menurut Gunawan (2015), tekanan titik saraf pada telapak kaki memberikan rangsangan bioelektrik yang dapat melancarkan sirkulasi aliran darah dan cairan tubuh untuk menyalurkan nutrisi serta oksigen ke sel-sel tubuh menjadi lancar yang akan memberikan efek relaksasi, dalam keadaan rileks inilah yang dapat memberikan stimulus ke Reticular Activating System (RAS) yang berlokasi di batang otak teratas yang dapat mempertahankan kewaspadaan dan terjaga. Keadaan rileks ini stimulus pada RAS akan semakin menurun. Dengan demikian akan diambil alih oleh batang otak yang lain yang disebut Bulbar Synchronizing Region (BSR). BSR akan melepaskan serum serotonin yang dapat memberikan efek mengantuk sehingga dapat meningkatkan kualitas tidur.

Hasil penelitian ini sesuai dengan teori Gunawan (2015), tekanan titik saraf pada telapak kaki memberikan rangsangan bioelektrik yang dapat melancarkan sirkulasi aliran darah dan cairan tubuh untuk menyalurkan nutrisi serta oksigen ke sel-sel tubuh menjadi lancar yang akan memberikan efek relaksasi, dalam keadaan rileks inilah yang dapat memberikan stimulus ke Reticular Activating System (RAS) yang berlokasi di batang otak teratas yang dapat mempertahankan kewaspadaan dan terjaga. Keadaan rileks ini stimulus pada RAS akan semakin menurun. Dengan demikian akan diambil alih oleh batang otak yang lain yang disebut Bulbar Synchronizing Region (BSR). BSR akan melepaskan serum serotonin yang dapat memberikan efek mengantuk sehingga dapat meningkatkan kualitas tidur.

Penelitian ini didukung oleh penelitian Wening (2014) tentang pengaruh 
massage kaki terhadap Intensitas nyeri pasca sectio caesaria di ruang bougenfil RSUD Dr. Adhyatma MPH. Institusi: Poliklinik Kebidanan Kemenkes RI, Semarang. Hasil penelitian diperoleh nilai $\mathrm{p}=0,001$ ( $\mathrm{p}$ velue $<0,05)$ menunjukan adanya perbedaan hasil sebelum dan sesudah diberikan massage kaki.

Menurut pendapat peneliti, pemberian massage kaki efektif dalam menurunkan insomnia. hal ini disebabkan massage kaki bisa membuat seseorang menjadi tenang dan rileks. Jadi dapat peneliti simpulkan ada pengaruh yang signifikan pemberian massage kaki terhadap penurunaninsomnia sebelum dan sesudah diberikan massage kaki pada Lansia dengan $\mathrm{p}$ value $0,001<\alpha=0,05$.

\section{SIMPULAN}

Berdasarkan tujuan penelitian dari hasil penelitian pengaruh massage kaki terhadap penurunan insomnia pada lansia maka dapat diambil beberapa kesimpulan sebagai berikut. insomnia pada lansia sebelum diberikan massage kaki sebagian besar mengalami insomnia sedang yaitu sebanyak 9 orang $(60 \%)$, insomnia pada lansia setelah diberikan massage kaki sebagian besar mengalami insomnia rendah yaitu sebanyak 13 orang $(86,7 \%)$, ada pengaruh yang signifikan pemberian massage kaki terhadap penurunaninsomnia sebelum dan sesudah diberikan massage kaki pada Lansia dengan $\mathrm{p}$ value $0,001<\alpha$ $=0,05$.

Bagi tenaga kesehatan dengan hasil ini diharapkan pihak tenaga kesehatan dapat menerapkan terapi alternative massage kaki untuk manangani lansia yang mengalami insomnia. Bagi peneliti selanjutnya diharapkan peneliti selanjutnya bisa meneliti faktor-faktor lain dengan metode berbeda dalam hal menurunkan insomnia.

\section{DAFTAR PUSTAKA}

Aspiani. 2014. Buku Ajar Keperawatan Gerontik. Jakarta: CV. Trans Info Media.

Associated Bodywork \& Massage Professional. 2015. Learn About Massage. Available: http://www.massagetherapy.com/lear nmore/index.php. (3 Pebruari 2018).

Aziz. 2014. Pengaruh Aromaterapi Sereh Terhadap Penurunan Insomnia Pada Lansia Di Panti Wredha Daerah Surakarta. Available: http://www.journal.ui.ac.id/home/(aks es 20 januari 2019)

Azizah. 2015. Keperawatan Lanjut Usia. Edisi 1.Yogyakarta : Graha Ilmu

Closky \& Bulechek. 2015.Massage Therapy Effects on African Americans with Type 2 Diabetes Mellitus: A Pilot Study. Journal of EvidenceBased Complementary \& Alternative Med.15(3) : p.149-155.

Darmojo. 2015. Geriatri (Ilmu Kesehatan Usia Lanjut). Jakarta: Balai Penerbit Fakultas Kedokteran Universitas Indonesia

Dewi \& Hartati. 2015. Pijat Refleksi+Obat Herbal. Yogyakarta : MediaBook

Dinas Kesehatan Provinsi Bali .2017. Profil Kesehatan Provinsi Bali. Denpasar : Dinas Kesehatan

Gunawan, D. 2015. Teknik Mudah \& Lengkap Pijat Refleksi : Cepat Sembuh dari Aneka Penyakit Operasi, Tanpa Suntik, Tanpa Biaya Mahal.Yogyakarta : Media Pressindo.

Kemenkes, RI. 2016. BuletinGambaran Kesehatan Lanjut Usia diIndonesia. Jakarta.

from:www.depkes.go.id/downloads/B uletinlansiapdf (accesed 14 Januari 2019)

Lumbantobing. 2015. Kecerdasan Pada Usia Lanjut Dan Demensia. Edisi 4. Jakarta: Balai penerbit FKUI. 
Maryam. 2015. Mengenal usia lanjut dan penangananya.Jakarta: Salemba Medika.

Prananto. 2016. Mengenal Sebab-Sebab, Akibat-Akibat, Dan Cara Terapi Insomnia. Yogyakarta: FlashBooks

Rahmawati. 2015. Efektifitas Mandi Air Hangat Dan Aroma Terapi LavenderTerhadap Insomnia Pada Lansia. Jurnal:Tesis Universitas Diponegoro

Siburian. 2014. Bagaimana Memberdayakan Kemampuan Fisik Lansia.(available)www.waspada.co.id /cetak/index.php?article_id=74423. Diakses tanggal 5 Pebruari 2018

Suarjani. 2015. Hubungan SelfCare Management dengan Kualitas Hidup Lansia Hipertensi di Desa Tegallalang Wilayah Kerja Puskesmas Tegallalang I Gianyar Tahun 2015. Skripsi StiKes Wira Medika PPNI Bali

Sudiyanto, Hendry., \& Wahid, Abdul. 2017. Pengaruh Terapi Dzikir Terhadap Insomnia pada pasien hospitalisasi. Tesis: Universitas Diponogoro.

Suryo. 2015. Depresi sebagai faktor terjadinya insomnia di Poli Geriatri RS Sardjito Yogyakarta, Tesis, Bagian Ilmu Kedokteran Jiwa fakultas kedokteran UGM, Yogyakarta.

Tappan \& Benjamin. 2014. Healing Massage Technique. Connecticcut : Appleton \& Lange.

Word Health Organitation. 2015. WHO Global Report on Falls Prevention in Older Age. Perancis: WHO 